\title{
Filipinas y Japón: dos hermanos que no lo parecen
}

DOI: $10.32870 /$ mycp.v3i11.115

$\mathrm{N}$ o obstante que las relaciones entre Filipinas y Japón datan ya de cuatro siglos, durante largo tiempo no pasaron de ser un comercio incipiente. Posteriormente, cuando a causa de la circunstancia históricoreligiosa japonesa el contacto se vio reducido al mínimo, hasta hace apenas poco más de un siglo que estas relaciones lentamente se reiniciaron.

Un recuento histórico de las relaciones entre Filipinas y Japón nos remitiría hasta el siglo XVI, época de intercambio en que los japoneses exportaban seda, algodón y utensilios domésticos a las Filipinas, además del comercio con los wako, comerciantes libres japoneses -que eran a la vez piratas-, y que mercaban paños de lana, campanas, perfumes, hierro, estaño, telas de algodón teñido y algunos artículos de menor tamaño a cambio de oro y de cera.

En aquellos tiempos las relaciones entre ambos países no eran precisamente amistosas. Los españoles de Filipinas temían la invasión japonesa, mientras que los japoneses sospechaban acerca de los verdaderos motivos que tenían los españoles para permanecer en aquel país. Al poco tiempo, el todavía incipiente intercambio se vio definitivamente deteriorado a consecuencia de la tortura y expulsión de cristianos por los japoneses, y de que Tokugawa Ieyasu decretara que solamente a los no cristianos y renegados les sería permitido comerciar. A su vez, el rey de España prohibió a los misioneros españoles viajar a Japón.

Corría el año de 1639 cuando los gobernantes Tokugawa decidieron interrumpir las relaciones de Japón con el resto del mundo, y en particular con los europeos, parcialmente porque éstas ofrecían a los disidentes japoneses la posibilidad de aliarse con alguna fuerza militar ajena al gobierno central, parcialmente

* Investigadora de la Universidad de Keio, Campus Fujisawa, Japón.
Silvia Novelo Urdanivia*

porque éstos habían abierto Japón a la "corrupción" a través de las ideas del cristianismo.

Fue entonces cuando la comunidad japonesa en las Filipinas, aunque bajo la estrecha vigilancia de los españoles, adoptó eventualmente al país como su hogar, y a pesar de que algunos de sus miembros lucharon en contra de los filipinos rebeldes, no fueron pocos los que contrajeron matrimonio con los nativos.

Hasta mediados de 1800 las relaciones entre los dos países se vieron restituidas, aunque su carácter de nuevo volvía a ser eminentemente económico.

Japón había visto siempre a Filipinas como un sitio ideal para la emigración de su creciente población y como fuente de materias primas y de alimentos. Los filipinos, por su parte, miraban en Japón a un aliado potencial en su lucha por la independencia de España. No obstante, a pesar de que de hecho había japoneses simpatizantes, los filipinos revolucionarios esperaron en vano la ayuda de Japón.

Los sentimientos que estos hermanos asiáticos abrigaban entre sí eran diversos. Por una parte, los japoneses eran vistos como intrusos que amenazaban el trabajo de los filipinos pero, por la otra, eran "amigos" que podrían ayudar a Filipinas a pelear en contra de sus colonizadores blancos, que finalmente perdieran este país en 1898.

La década de 1920 fue de gran significado tanto para Filipinas como para Japón, porque cubre un período en el que ambos países emprendían su camino hacia el liberalismo. No obstante, la siguiente década, cuando Filipinas avanzaba implacable hacia la independencia bajo un gobierno democrático, Japón desviaba sus pasos hacia el militarismo. 
También fue durante los años veinte que Japón se convirtió en el mayor socio comercial de Filipinas después de Estados Unidos. De 1920 a 1938 , entre 8 y 12 por ciento del total de importaciones filipinas llegaron de Japón. Las relaciones estuvieron centradas en dos tipos de actividad económica, la primera en las inversiones japonesas y la segunda en la importación y exportación de trabajadores japoneses.

A lo largo del período de dominio estadounidense los planes expansionistas de Japón en Filipinas finalmente se hicieron realidad. En los años previos al estallido de la Segunda Guerra Mundial, los japoneses en las filipinas constituían ya varias decenas de miles: ellos habían llegado para trabajar como obreros especializados, comerciantes, campesinos y pequeños hombres de negocios; mientras que las mujeres se dedicaron a desempeñar labores de niñeras, prostitutas, cantantes en clubes nocturnos $y$ peluqueras.

En un intento por arrancar de los rostros filipinos las máscaras españolas y estadounidenses para hacer lucir en ellos "lo oriental”, Japón trató de repetir, con un mínimo de interferencia extranjera, lo hecho por él mismo durante el período Meiji: modernizarse de manera selectiva, tomando prestado únicamente lo deseado y, a través de un proceso de adaptación, alcanzar una distintiva modernización. Desafortunadamente, la ocupación japonesa en Filipinas acabó por convertirlo en el tercer país que privaba a los filipinos de la oportunidad de vivir una experiencia cultural semejante.

\section{¿Fue la de 1941 una invasión planeada por décadas?}

El cada vez más creciente número de residentes japoneses en las Filipinas y el aumento de sus inversiones y de su comercio en el país constituían el otro lado de la imagen japonesa; ¿era Japón un aliado o una amenaza?

Las relaciones culturales eran de hecho débiles y desiguales. El aspecto económico eclipsaba al cultural. Japón invadió Filipinas en 1941, convirtiendo los antiguos temores en realidad, a pesar de que la expansión japonesa en la economía filipina no hubiera sido -como muchos críticos sostienen- debida a la agresividad nipona. Por un lado, fue una expansión derivada de la tolerancia por parte de los administradores coloniales estadounidenses $\mathrm{y}$, por el otro, de la astuta diplomacia japonesa y el oportunismo de los propios filipinos. Y hoy todavía sus efectos pesan sobre las relaciones entre ambos países asiáticos.

Los japoneses estuvieron en Filipinas solamente tres años (de 1941 a 1945) pero para los filipinos representaron los tres más largos años de toda su historia; años iniciados y finalizados con batallas; años que presenciaron fuertes movimientos de resistencia por las guerrillas antijaponesas y la brutal respuesta nipona; años de muerte, dolor, incertidumbre y temor; de pérdida de la paz y el orden; años de graves problemas económicos y de escasez de alimentos.

Todo lo que se ha escrito hasta la fecha por los especialistas acerca de este período puede quedar clasificado en dos grandes categorías: lo publicado en las áreas ocupadas por los japoneses y lo dado a conocer fuera de ellas. Sin 
embargo, y a pesar de que el paso de más de cinco décadas ha atenuado el enojo y la enemistad, mitos y estereotipos continúan vigentes.

El 4 de julio de 1946 Filipinas recuperó su independencia e, irónicamente, iniciaron una nueva relación con un también nuevo Japón, un Japón ahora ocupado. Desde principios de la década de los cincuenta comenzaron las negociaciones para alcanzar un tratado de paz con su hermano asiático y para discutir las reparaciones de guerra. En septiembre del 51, Carlos P. Rómulo firmó a nombre de las Filipinas el Tratado de Paz con Japón; en 1953 el presidente Elpidio Quirino había otorgado ya la amnistía a todos los acusados.

Tras elfin de la Segunda Guerra Mundial, cinco décadas atrás, las relaciones de estos dos países han pasado por buenos y malos ratos. Pero a partir de que Japón se convirtiese en una potencia económica y que como tal haya apoyado a Filipinas mediante la Ayuda Oficial Japonesa (ODA) y las Inversiones Extranjeras Directas (IED), las expectativas de un mayor acercamiento más «fraternal», no suenan ya como una idea descabellada. En particular, son vistas a la luz de los últimos avances económicos de las Filipinas, en donde los marcadores de la modernidad evocan ahora, más que nunca, las innovaciones tecnológicas de Japón. Ti: 